\title{
Digital Food Delivery Apps Revolutionizing Food Products Marketing in India
}

\author{
N. Thamaraiselvan, G. R. Jayadevan, K. S. Chandrasekar
}

\begin{abstract}
Food delivery aided through digital apps has emerged as one of the fast-growing developments in the e-commerce space. The advent of digital tools has bestowed a different outlook on the food industry. Consumers today have the privilege to choose from a variety of cuisines, anywhere, anytime from a range of food providers listed in the e-commerce space. Added attractions like no minimum order value and the multitude of payment options like net banking, digital wallets, and cash on delivery all have increased the consumer convenience. Shrinking urban-rural divide with easy access to smartphones has hastened the growth and acceptance of online food delivery systems. Companies have remodelled their business strategies on a modern day digital platform to keep pace with the customer's changing needs and preferences. In this paper, we particularly examine the growth and relevance of digital apps in the food delivery systems run by the food providers particularly fast food companies in India and a few strategies which could be adopted by them for sustainable business in the days to come.
\end{abstract}

Keywords: Digital Apps, e-Commerce, Food Products Marketing, Consumer Choice

\section{INTRODUCTION}

The business of delivering ready to eat foodstuffs from restaurants to home is undergoing a sea change as new online platforms enable food providers to capture markets and customers day by day. Worldwide, the food delivery market stands at 4 percent of food items sold through restaurants chains and fast-food outlets. This market has already matured in many countries with a growth rate estimated at 3.5 percent for five years down the line (McKinsey, 2016). The picture is not so different in our country as well. The conventional mode of food delivery wherein customers order food online through the websites of restaurants, or fast-food chains have now been replaced with the concept of 'aggregator business model.' Here the business player provides a 'single window system' variety of food providers registered on the portal. The 'aggregator' would charge a fixed margin of the order from the food provider and in turn, handles the delivery of the food item at the doorstep of the consumer. The focus has now shifted from technology to logistics, which is currently acting

Revised Manuscript Received on July 22, 2019.

N. Thamaraiselvan*, Department of Management Studies, National Institute of Technology, Tiruchirappalli, Tamil Nadu, India. Email: Institute of Technology, Tiruchirappalli, Tamil Nadu, India. Email: jayadevan.nitt@gmail.com

K. S. Chandrasekar, Institute of Management in Kerala, University of Kerala, Thiruvananthapuram, Kerala, India. Email: kscnair@gmail.com enabling the customers to order food online from a wide selvanthamarai27@gmail.com

G. R. Jayadevan, Department of Management Studies, National

as the major cost drivers for the food industry. Despite escalating traveling and vehicle maintenance costs, these food delivery companies make profits by up to $30 \%$ (Mckinsey, 2016).

Indian consumers habituated to online shopping experience through digital apps and e-commerce websites with maximum convenience and transparency would expect the same when it comes to the matter of online food ordering as well (Kapoor and Vij, 2018). Just next to grocery items, food delivery proved to be a big opportunity for Indian e-commerce companies. Online food delivery market in India, comprising of aggregators and internet kitchens, showed a spectacular growth in recent years. The market in India is of the tune of 15 billion USD and is all set for an exponential growth phase (Kanteti, 2018). The sector is very competitive, and growth of online food ordering via digital platform made the businessmen and entrepreneurs awake and took notice. Some popular 'food aggregators' like Zomato, Swiggy, Food Panda, and UberEats are feeding the Indian cities online and making decent profits. Various food delivery web portals and mobile apps offer the rational Indian customer a direct comparison between the prices and rating of different food outlets and restaurants serving the same dishes and to choose among the various options (Gera et al., 2018).

\section{METHODOLOGY}

This paper is purely analytical based on the available secondary data. Existing literature was thoroughly analyzed to explain the trends and patterns in the 'Digital Food delivery' market in India. Secondary data was explored to identify and explain various variables that drive the acceptability of 'food aggregators' in Indian food marketing scenario, the newer trends, and future market. The secondary data sources used were sales reports available from the official websites of various companies, published documents, survey reports, reports released by Government agencies and Marketing Research agencies.

\section{DISCUSSION}

\section{A. Growth Drivers}

India, with population of over 1.3 billion, is undoubtedly a big consumer market across the globe. We have more than $50 \%$ of our population below the age of 25 and more than $65 \%$ below the age of 35 years. It is estimated that, in 2020 , the average age of an Indian will be 29 years, compared to 37 for China and 48 for Japan which would make India, a nation with the youngest population in the world too. 
Youth populations below 40 years demand more fast food items in their diet (Kharas, 2017). Young Indian appetite would be one of the major growth drivers for food and beverage sector on the whole.

Indian youth productively employed in high-earning fields like IT/ITES, banking and financial services, tourism, and hospitality have scaled up their standard of living and made their wallets heftier. A recent study conducted by the World Bank revealed a remarkable $50 \%$ hike in per capita income in India during the period from 2006 to 2016 . Urban-rural divide is shrinking in the country. Almost all cities in India witness a visible change in the social setting, which further propelled the mushrooming of fast food outlets across the length and breadth of the country.

Lifestyle changes mainly in Urban India with double-income earners in families, crunch on quality time for spending with family members, changing food habits all have resulted in growing demand for speedy access to food items especially cooked food stuffs at affordable rates. More women became earning members in their families, with the result that they spend most of their productive hours for commuting and at work. There will be less time at their disposal to cook full blown meals at home, all by themselves. In such situations, employed women generally spend a large portion of their disposable income on buying take outs or eating out.

Nowadays, more and more restaurants and food outlets offer global cuisines. More Indians, particularly those dwelling in urban centers, tryout new cuisines, with the result that the number of times they dine out increase, thus positively influencing the overall Indian food industry. There exists a symbiotic association between the growth of retailing and the proliferation of international food brands and restaurant chains in the country. The food providers identified retail malls to be ambient for getting more customers who visit malls for shopping. On the other side, more customers dining at food outlets obviously perform shopping at the shops in retail malls too. Hence a 'synergy' is developed between the parties.

Door delivery focused food business demands lesser initial investment when compared to opening up a restaurant be it for the matter of rent, interior designing, or cost of furniture. Such cost benefits lure more and more operators to dedicate their time, money, and energy in these food business options. The operators can enjoy considerable cost cuts in terms of labor, supplies, and the need for aesthetic store locations, which is the costliest of all investments in restaurant business.

\section{B. Experimenting with the Business Portfolio}

The fast-food joints and restaurant chains keep on offering more door delivery services with an aim to maximize their business output. They target on rationalizing the existing fixed costs and also keeping their business sustainable. The food business operators have identified home delivery to be an essential ingredient in their product mix. Food outlets whether big or small; all are striving to get a share in the digital business. Moreover, with this format, comparatively more number of customers can be serviced, than the conventional 'sit-and-dine' format where at busy hours; lot of customers may be missed. The door delivery format would also keep customer loyalty robust.

\section{Technology is the Power}

Many players are entering the Indian food business sector consequent to the growing usage of internet and smart phones among customers. As a general rule, the success of any business lies in certain vital factors. To perform a precise market study, the choice of updated technology and the future vision of the company are most relevant. The choice of updated technology has proven its role by boosting the market share, building competitive advantage, and improving profit margins for the company. In the present digital era with mammoth size data available, Information and Communication Technology can be utilized as an effective tool to gain competitive edge over other players in the market. A company can obtain valuable insights by analyzing the data and take more appropriate decisions. The food aggregators need to quickly realize the challenges associated with the adoption of technology and work towards solving such issues. They need to create a platform that provides an 'user engaging experience' which ultimately increases customer satisfaction levels and loyalty.

\section{New Trends}

Smartphone literacy has increased over the past few years, with cheaper access to the internet. The growing relevance of mobile-based food delivery apps and website-based food ordering platform cannot be ignored at this juncture. Well known brands like Domino's Pizza delivers over 50,000 pizzas in a day and 15,000 of those orders are placed through the digital mode. Fassos, another popular food chain caters to over 60,000 orders in a day all through their in-house mobile app. In the recent time, these big players have joined hands with online food service site Food Panda with the result that the number of food orders would double in the years to come. With the success of E-Tailing, all delivery-based 'quick service restaurants' (QSR) would have better prospects for earning more than the revenues generated from their conventional business models.

\section{E. Challenges in Operational Efficiency}

To derive the best possible operational efficiency would be the greatest challenge of any food aggregator in India. Indian business is considered to be of comparatively lower margin portfolio for majority of the food companies. Many players operate with poor profits thus posing severe hurdles for their mere sustenance in the market. It becomes extremely difficult for any company to charge a decent sum of money from the consumers to make it operationally sustainable. Use of low cost technologies and strategies to operate, innovate and create value for the end-user is the need of the hour. To cite an example, Zomato, one of the leading food aggregators in India, started offering varied products and services to generate more revenue. Products like Zomato Base, Zomato Book, and Zomato White label, along with business consultancy services have made

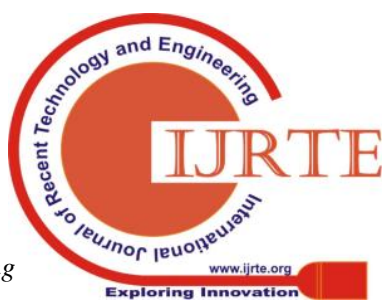


the revenue model more sustainable (Chadda, 2012).

\section{F. Skeptical Business}

The Food Safety and Standards Authority of India (FSSAI), the food safety regulator in India recently cautioned the 'food aggregators' for placing unverified food outlets on their digital platforms. The authority directed them to ensure proper training and capacity building of restaurant partners in the business to improve food safety and hygiene instead eyeing only on huge discounts and aggressive marketing strategies.

The way the food aggregators now operate offering deep discounts, cut-throat competition, and lack of food safety checks would adversely affect the survival chances of these players in the long run. Restaurant chains and food outlets, now part of this platform are little cautious not to be too much reliant on this line of business. Many have revamped their in-house food ordering apps. They prefer preserving the in-house delivery infrastructure, even when the aggregator business is expanding. To cite an example is the Jubilant Food works running the Domino's Pizza chain stores in India recently updated their in-house app and secured an overwhelming response from the customers. A similar case is that of McDonald's outlets in India. Both their online ordering and delivery platform, as well as third-party food apps, have grown complementary over the past few years.

\section{IMPACT}

The business format of delivering ready-to-eat food over a digital platform either through a web portal or mobile apps has captured more customers to its ambit particularly in places like retail malls, housing apartments and office locations. The customer today admires the online food ordering and delivery mechanism. Everyone would admit that convenience and time savings are the major attractions of this business model. Moreover people now in the midst of their busy life style prefer restaurant type food items of varied cuisines in the privacy of their homes or office locations. The Indian fast-food business sector is about twenty years old and still remains unorganized. Considering the present growth patterns in organized restaurant business sector, it is sure that tremendous impact would soon happen on the existing restaurant businesses without own delivery-focused formats and it is only a matter of time and some significant global investments.

\section{CONCLUSION}

Rapid urbanization connected with the influx of professionals in urban centers and exposure to western lifestyle is aiding the spectacular growth of food delivery and restaurant segment in India. Adding to this scenario is the increase in usage of smartphones and food delivery apps. These have become a big hit in the food industry with a growing number of tech-savvy customers using food delivery apps at the comfort of their homes and offices. Present day food tech space offer many business models. To name a few, are on-demand delivery, cloud-kitchen, thin layer, full stack, restaurant and food discovery, concierge, market place, and home cooked food models. Most valued, the toughest and unexplored one among these is the Home cooked food model (Kanteti, 2018). Thus innovation can spin off the restaurant business in a wholly new direction. Technology and innovation will now dictate the growth of this sector. Technology is the potential tool to offer high cost and efficiency improvements for food providers as well as customer ecstasy at the other end.

\section{REFERENCES}

1. Bajaj, K. \& Mehendale, S. (2016). Food - Delivery Start-Ups: In Search of the Core. Prabandhan: Indian Journal of Management, Volume 9, Issue 10 .

2. Bhargava, A., Jadhav, N., Joshi, A., Oke, P., \& Lahane, S. R. (2013). Digital ordering system for Restaurant using Android. International Journal of Scientific and Research Publications, Volume 3, Issue 4.

3. Gera, M., Nawander, N., Tharwani, N. \& Bhatia, P. (2018). Operations research in food delivery. International Journal of Advance Research and Development, Volume 3, Issue 10, Pages 73-78.

4. Hannu, S., Lasse, M. \& Yrjölä, M. (2014). From selling to supporting Leveraging mobile services in the context of food retailing. Journal of Retailing and Consumer Services, Volume 21, Issue 1, Pages 26-36.

5. Kanteti, V. (2018). Innovative strategies of startup firms in India - A study on online food delivery companies in India. International Research Journal of Management Science \& Technology, Volume 9, Issue 3, Pages 17-23.

6. Kapoor, A. P. \& Vij, M. (2018). Technology at the dinner table: Ordering food online through mobile apps. Journal of Retailing and Consumer Services, Volume 43, Pages 342-351.

7. Kashyap, K. (2017, June 26). The Food Delivery Apps That Are Competing To Gain Market Share in India. Retrieved from https://www.forbes.com/sites/krnkashyap/2017/06/26/the-food-deliver $\mathrm{y}$-apps-that-are-competing-to-gain-market-share-in-india/\#56bc21ad19 93 (accessed on May 29, 2019).

8. Kharas, Homi. 2017. The unprecedented expansion of the global middle class: An update. (C) Brookings, India. http://hdl.handle.net/11540/7251.

9. Kimes, S. E. (2011). Customer perceptions of electronic food ordering Cornell Hospitality Report, Volume11, Issue 10, Pages 6-15 https://scholarship.sha.cornell.edu/cgi/viewcontent.cgi?article $=1069 \& \mathrm{c}$ ontext $=$ chrpubs

10. Mckinsey. (2016, November). Retrieved from https://www.mckinsey.com/industries/high-tech/our-insights/the-chang ing-market-for-food-delivery (accessed on May 29, 2019).

11. Raman, P. (2018): Zomato: a shining armor in the food tech sector, Journal of Information Technology Case and Application Research, DOI: $10.1080 / 15228053.2018 .1552396$.

12. https://economictimes.indiatimes.com/markets/stocks/news/indias-con sumption-story-why-you-just-cant-ignore-this-opportunity/articleshow/ 66346111.cms?from=mdr (accessed on June 2, 2019).

13. https://economictimes.indiatimes.com/small-biz/startups/newsbuzz/swi ggy-zomato-in-top-gear-as-ride-hailing-companies-slow-down/articles how/69405510.cms (accessed on June 2, 2019).

\section{AUTHORS PROFILE}

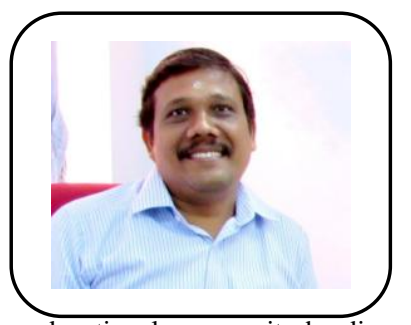

Dr. N. Thamaraiselvan, MBA, MPhil, $\mathrm{PhD}$ is the Professor (Marketing) at the Department of Management Studies, National Institute of Technology, Tiruchirappalli, Tamil Nadu, India. With over 25 years of academic and industrial experience, he proved to be a passionate academician with incessant drive to contribute the best to educational community by discovering innovative pedagogical techniques in the teaching learning process. He served the positions of Associate Dean (Administration) and Head, Department of Management Studies of the National Institute of Technology, Tiruchirappalli. His active commitment to research made him to publish more than 40 articles in referred journals and present research papers in several national and international conferences. 


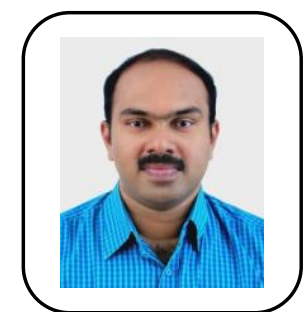

G. R. Jayadevan, B.Tech (Dairy Technology), MBA, PGDM, PGD-PRM, UGC-NET is an Assistant Professor in the Department of Dairy Business Management, Faculty of Dairy Science, Kerala Veterinary and Animal Sciences University, Wayanad, Kerala. He is currently pursuing Doctoral Programme in Management Studies (on Study Leave) at the National Institute of Technology, Tiruchirappalli, Tamil Nadu, India. With 12 years of teaching and administrative experience, he published 11 research articles and several popular articles in reputed journals and magazines.

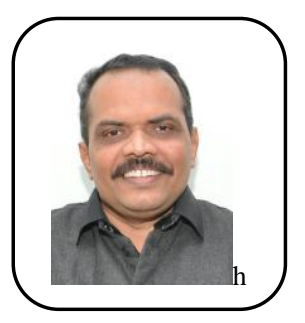

Dr. K. S. Chandrasekar, B. Pharm (Hons.), MBA, MS, CPET, PGDHP, PhD, Post-Doctoral Degree (Commonwealth Open University, Spain) is the Professor, Institute of Management in Kerala, University of Kerala and Formerly, Dean of Faculty of Management studies and Chairman- Board of Studies in Business Management of the University of Kerala. He is presently the Vice Chairman, Centre for Management Development, Trivandrum (A Government of Kerala institution). With 22 years of teaching MBA, M.Phil. Programmes at Alagappa University and University of Kerala specializing in Marketing, Strategic Management and HRM, he could author seven books in Management area, published 161 research articles and presented 179 research papers in several national and international conferences. 